\title{
Inner Surface of Pterion in Terms of Surgical Approaches: An Anatomical Cadaveric Study
}

\section{Cerrahi Yaklaşımlar Açısından Pterionun İç Yüzeyi: Anatomik Kadavra Çalışması}

(1) Sedat DEVELİ1, iD Royal MEHTIYEV²

1'University of Health Sciences, Gülhane Faculty of Medicine, Department of Anatomy, Ankara, Turkey

${ }^{2}$ Bas Military Clinical Hospital, Clinic of Neurosurgery, Baku, Azerbaijan

\section{ABSTRACT}

Objective: Aim of this study was to evaluate the morphometric features and the inner surface of the pterion in terms of surgical procedures for neighboring anatomical structures.

Methods: Thirty five skeletally mature craniums were included in the present study. Fifteen of the craniums were belonged to cadavers, 20 of the craniums were dry bones. All specimens were obtained from the department of anatomy. Type of pterion and distance of midpoint of pterion to palpable surface landmarks were noted. Inner surface of pterion was marked by translumination of a laser pointer. Overlap of pterion with important anatomical structures and its closest distance to them was evaluated.

Results: The most common type of pterion was sphenoparietaltype $(80 \%)$ and the least common type was epipterical (1.4\%) type. The mean thickness of the calvaria on the pterion was $4.2 \pm 016$ $\mathrm{mm}$. Pterion is located approximately $4 \mathrm{~cm}$ superior and $2.5 \mathrm{~cm}$ anterior to midpoint of arcus zygomaticus; $3 \mathrm{~cm}$ superior and 1.5 $\mathrm{cm}$ posterior to tuberculum marginale; $7 \mathrm{~cm}$ superior and $6.5 \mathrm{~cm}$ anterior to the tip of processus mastoideus. In $61.4 \%(n=43)$ of samples, inner surface of pterion was found to be associated with groove of a. meningea media. In $81.4 \%(n=57)$ of specimens, inner projection was coincided with sinus sphenoparietalis. Foramen spinosum was located posteroinferior to inner projection and the mean closest distance was $39.8 \pm 6.53 \mathrm{~mm}$. Meckel cave was located posteromedial to inner projection and the mean closest distance was $40.6 \pm 3.18 \mathrm{~mm}$.

\section{ÖZ}

Amaç: Bu çalışmanın amacı pterionun morfometrik özelliklerini ve pterionun iç yüzeyini, komşu anatomik yapılar için yapılan cerrahi prosedürler açısından değerlendirmektir.

Yöntemler: Çalışmaya, iskelet gelişimi tamamlamış 35 kafatası dahil edildi. Kafataslarından 15'i kadavralara aitti, 20 tanesi kuru kemik idi. Tüm örnekler anatomi anabilim dalından alınmıştır. Pterion tipi ve pterionun orta noktasının palpabl yüzey işaret noktalarına olan uzaklığı kaydedildi. Pterionun iç yüzeyi, bir lazer işaretçinin translüminasyonu ile işaretlenmiştir. Pterionun önemli anatomik yapılarla örtüşmesi ve onlara olan en yakın mesafesi değerlendirildi.

Bulgular: Pterionun en yaygın görülen tipi sphenoparietal tip $(\% 80)$, en az gözlemlenen tipi epipterik tip pterion $(\% 1,4)$ idi. Kalvaria’nın pterion üzerindeki ortalama kalınlığı 4,2 $\pm 0,16 \mathrm{~mm}$ olarak ölçüldü. Pterion, arcus zygomaticus'un orta noktasına göre yaklaşık $4 \mathrm{~cm}$ üstte ve $2,5 \mathrm{~cm}$ önde; tuberculum marginale'ye göre $3 \mathrm{~cm}$ üstte ve $1,5 \mathrm{~cm}$ arkada, processus mastoideus'a göre $7 \mathrm{~cm}$ üstte ve $6,5 \mathrm{~cm}$ önde yer alıyor olarak bulunmuştur. Örneklerin $\% 61,4$ 'ünde $(\mathrm{n}=43)$ pterionun iç yüzeyi a. meningea media’nın oluğu ile ilişkili bulunmuştur. Örneklerin \%81,4’ünde ( $\mathrm{n}=57)$ ise sinüs sphenoparietalis ile çakışmaktaydı. Foramen spinosum posteroinferior yerleşimde ve ortalama en yakın mesafesi 39,8 $\pm 6,53$ $\mathrm{mm}$ idi. Meckel oluğu posteromedial yerleşimde ve ortalama en yakın mesafe 40,6 $\pm 3,18 \mathrm{~mm}$ idi.

Sonuç: Sinüs sphenoparietalis ve a. meingea media'nın frontal dalı, pterionun iç yüzeyi ile çakışan başlıca anatomik yapılardır.
Address for Correspondence: Sedat DEVELi, University of Health Sciences Gülhane Faculty of Medicine, Department of Anatomy, Ankara, Turkey

Phone: +90 5415272700 E-mail: drsedatdeveli@gmail.com ORCID ID: orcid.org/0000-0002-3712-7510
Received: 28.03.2018

Accepted: 09.04.2019

Cite this article as: Develi S, Mehtiyev R. Inner Surface of Pterion in Terms of Surgical Approaches: An Anatomical Cadaveric Study. Bezmialem Science 2020;8(1):26-30. 
Conclusion: Sinus sphenoparietalis and frontal branch of a. meningea media are the main anatomical structures overlapping with internal aspect of pterion. In order to minimize complications, these anatomical structures should be kept in mind during pterional craniotomies.

Keywords: Pterion, arteria meningea media, sinus sphenoparietalis
Komplikasyonları en aza indirgemek için pterional kraniyotomiler sırasında bu anatomik yapılar akılda tutulmalıdır.

Anahtar Sözcükler: Pterion, arteria meningea media, sinüs sphenoparietalis

\section{Introduction}

Cranial part of the central nervous system is enclosed by neurocranium. In the adult cranium, bones forme the neurocranium articulate by joining with each other via sutural joints. In the embryo, junctions of these sutural joints are not calcified. Membranes covering spaces between these junctions are called fontanelles. In human fetus, six fontanelles are found in the neurocranium. Two of them are seen on the superior of the skull which are called anterior and posterior fontanelles. Four of them are located on the lateral side of cranium. Anteriorly located ones are called sphenoid fontanelles and the posteriorly located ones are called mastoidal fontanelles (1).

In the adult, the sphenoid fontanelle becomes pterion by calcification which is the junction of the sutura on the anterolateral side of the neurocranium (1). Pterion is also known as the thinnest part of the calvaria (2). Pterion is often used as surgical landmark especially for the transsylvian approach in order to reveal frequently seen vascular or parenchymal lesions $(3,4)$. On the other hand, pterion is also used as marking point for the branches of a. meningea media, in terms of epidural hemorrhage during lateral craniotomies (5).

In this study, we aimed to reveal the morphometric features of the pterion and its relationship with the vascular and dural anatomical structures which is important for lateral surgical approaches.

\section{Methods}

Ethics committee approval was taken from the local ethical committee (KEAH - 2017 - 1564).

A total of forty skeletally mature adult craniums were included in the present study. Twenty of the craniums were dry bones, twenty of the craniums belonged to adult cadavers. Cadavers were obtained from the department of anatomy. Cadavers were fixed with formaldehyde and they belonged to Caucasian subjects. Age of the cadavers were unknown. Five of the craniums with fracture or previous dissection regarding pterion region were excluded from the study. A total of thirty five craniums and seventy sides (fifteen dry bones, twenty cadaveric) were included for the study.

Pterion was revealed on the lateral side of the cranium. Formation pattern of the pterional junction was noted according to the Murphy Classification which was described in 1956 (6). In order to locate the position of the pterion, mid-point of arcus zygomaticus, tuberculum marginale, and tip of the processus mastoideus were used as bony landmarks. Since these landmarks are palpable under the surface of skin, location of the pterion can be found easily during surgeries without any further skin incisions. External cranial landmarks and measurement points are shown in Figure 1.

Inner surface of the pterion is in close relationship with a. meningea media and sinus sphenoparietalis. In order to assess this relationship, translumination with laser pointer was used and inner projection of the pterion was marked. The relationship of the inner projection of pterion with a. meningea media and sinus sphenoparietalis was evaluated. Distance of the inner projection to foramen spinosum and Meckel cave, and thickness of the calvaria on the pterion were also measured. A digital caliper was used for measurements on the specimens. All measurements were repeated 3 times and mean value of three measurements wasaccepted as the final distance. Photographs were taken by digital camera (Canon Ixus 115).

\section{Statistical Analysis}

Descriptive analyses were made for all variables. Statistical results were represented as mean \pm standard deviation. Student's t-test was performed to compare the measurements of left and right

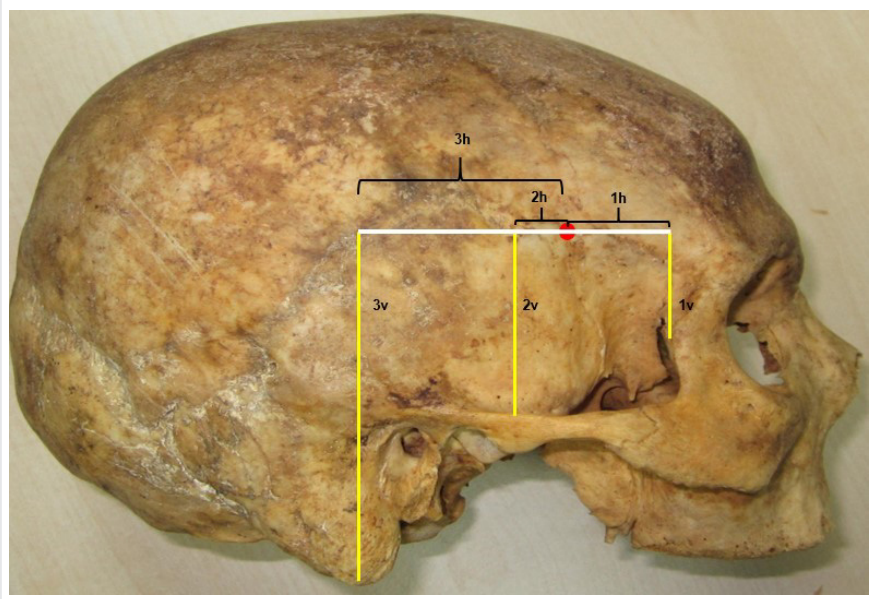

Figure 1. Landmarks used for morphometric measurements Easily palpable surface landmarks are used for measurements.

1: Tuberculum marginale, $1 \mathrm{v}$ : Vertical distance to pterion, 1h: Horizontal distance to pterion, 2: Midpoint of arcus zygomaticus, 2v: Vertical distance to pterion, 2h: Horizontal distance to pterion,

3: Tip of processus mastoideus, 3v: Vertical distance to pterion, 3h: Horizontal distance to pterion 
sides. All analyses were done using SPSS (version 15) software with a statistically significance level of $p<0.05$. This study was conducted after it was approved by the local ethical committee.

\section{Results}

The most common type of the pterion was sphenoparietal type in the present study (80\%) (Figure 2A). The least observed pterion type was the epipterical type of pterion (1.4\%) (Figure $2 \mathrm{~B})$. The frequencies of pterion types are given in Table 1. The mean thickness of the calvaria on the pterion was measured as $4.2 \pm 0.16 \mathrm{~mm}$.

In order to locate pterion easily during surgeries, palpable bony landmarks were chosen. Vertical and horizontal distances between pterion and these landmarks are given in Table 2. According to our results, pterion was located approximately $4 \mathrm{~cm}$ superior and $2.5 \mathrm{~cm}$ anterior to midpoint of the arcus zygomaticus, 3 $\mathrm{cm}$ superior and $1.5 \mathrm{~cm}$ posterior to tuberculum marginale, $7 \mathrm{~cm}$ superior and $6.5 \mathrm{~cm}$ anterior to the tip of the processus mastoideus.

Inner surface of the pterion was marked by translumination from the exterior of the cranium. Relationship of the inner surface of the pterion with vascular and dural structures was observed. In $61.4 \%(n=43)$ of the samples, inner surface of the pterion was found to be associated with groove of a. meningea media (Figure 3). This relationship was associated with the frontal

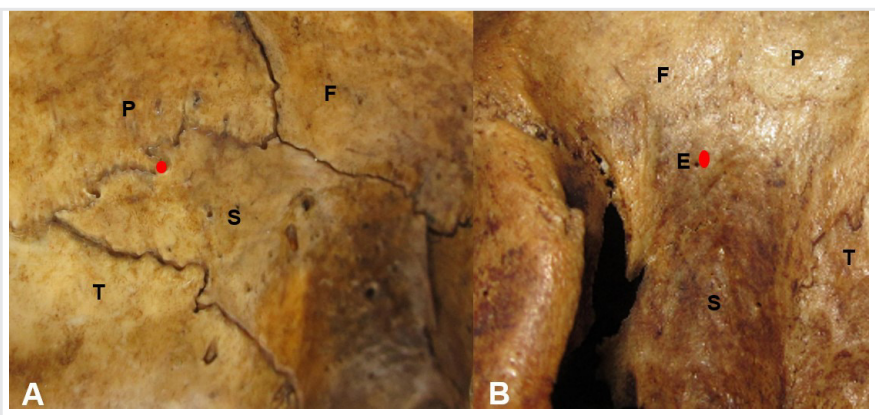

Figure 2. The most common and the least common types of pterion

A) Sphenoparietal type is the most common observed type,

B) Epipterical type is the least common observed type in this study

\begin{tabular}{|l|l|l|l|}
\hline \multicolumn{4}{c}{ Table 1. Frequency of Pterion types } \\
\hline Sphenoparietal & Frontotemporal & Epipterical & Stellate \\
\hline $80 \%(n=56)$ & $15.7 \%(n=11)$ & $1.4 \%(n=1)$ & $\sim 2.9 \%(n=2)$ \\
\hline
\end{tabular}

ramus of the a. meningea media in all of the samples. Bifurcation of the a. meningea media to frontal and parietal branches was $17.3 \pm 1.6 \mathrm{~mm}$ inferior to inner projection. In $81.4 \% \quad(\mathrm{n}=57)$ of the specimens, inner projection was coincided with sinus sphenoparietalis (Figure 3, 4). Foramen spinosum was located posteroinferior to the inner projection and the mean closest distance was $39.8 \pm 6.53 \mathrm{~mm}$. Meckel cave where the trigeminal ganglion is found was located posteromedial to inner projection and the mean closest distance was $40.6 \pm 3.18 \mathrm{~mm}$.

Statistical analyses of the data revealed that no significant difference was found between right and left sides $(\mathrm{p}>0.05)$.

\section{Discussion}

The pterion which is located on the anterolateral side of the cranium is the junction of four neurocranium bones: Temporal, frontal, sphenoid and parietal bones (1). Since inner surface of the pterion is associated with important anatomical structures such as a. meningea media or Sylvian fissure, it is commonly used as an important extracranial landmark (3). The appearance of the conjunction of the pterion varies. The most common classification used for the appearance of the pterion is the Murphy classification (6). The sphenoparietal type pterion (Type A according to Murphy Classification) is the most common observed pterion type and our findings are consistent with the literature. The rarest type of pterion varies due to ethnic differences $(2,7)$. In the current study, epipterical type was the least observed type (Type C).

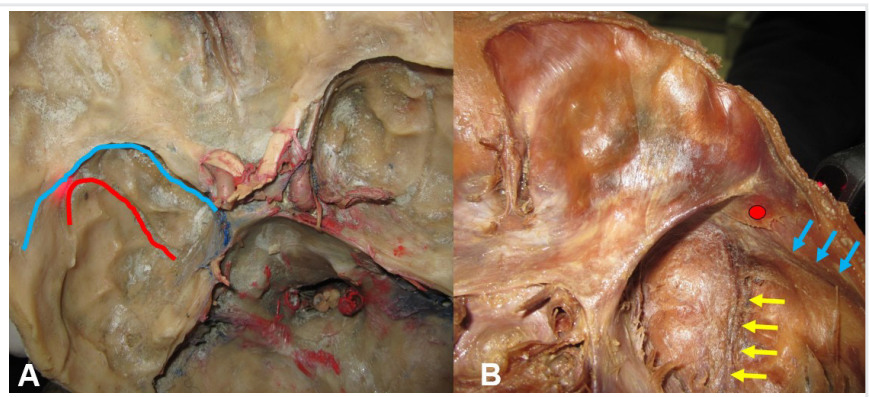

Figure 3. Internal aspect of the pterion

A) Overlapping of sinus sphenoparietalis and a. meningea media on the pterion. Blue line indicates the course of the sinus sphenoparietalis. Red line indicates the groove of the a. meningea media, B) Inner surface of the pterion does not coincide with dural sinus or meningeal vessels. Blue arrows: sinus sphenoparietalis, yellow arrows: meningeal vessels. Red circle indicates the inner surface of the pterion

Table 2. Distances between pterion and bony landmarks

\begin{tabular}{|c|c|c|c|c|c|c|}
\hline & \multicolumn{2}{|c|}{ Tuberculum marginale } & \multicolumn{2}{|c|}{ Midpoint of arcus zygomaticus } & \multicolumn{2}{|c|}{ Tip of processus mastoideus } \\
\hline & $\begin{array}{l}\text { Vertical distance to } \\
\text { pterion }\end{array}$ & $\begin{array}{l}\text { Horizontal } \\
\text { distance to } \\
\text { pterion }\end{array}$ & $\begin{array}{l}\text { Vertical distance to } \\
\text { pterion }\end{array}$ & $\begin{array}{l}\text { Horizontal } \\
\text { distance to } \\
\text { pterion }\end{array}$ & $\begin{array}{l}\text { Vertical distance to } \\
\text { pterion }\end{array}$ & $\begin{array}{l}\text { Horizontal } \\
\text { distance to } \\
\text { pterion }\end{array}$ \\
\hline $\begin{array}{l}\text { Midpoint of } \\
\text { pterion }\end{array}$ & $31.46 \pm 1.25$ & $14.73 \pm 0.37$ & $42.58 \pm 3.62$ & $24.81 \pm 2.49$ & $69.14 \pm 5.02$ & $65.48 \pm 4.24$ \\
\hline
\end{tabular}




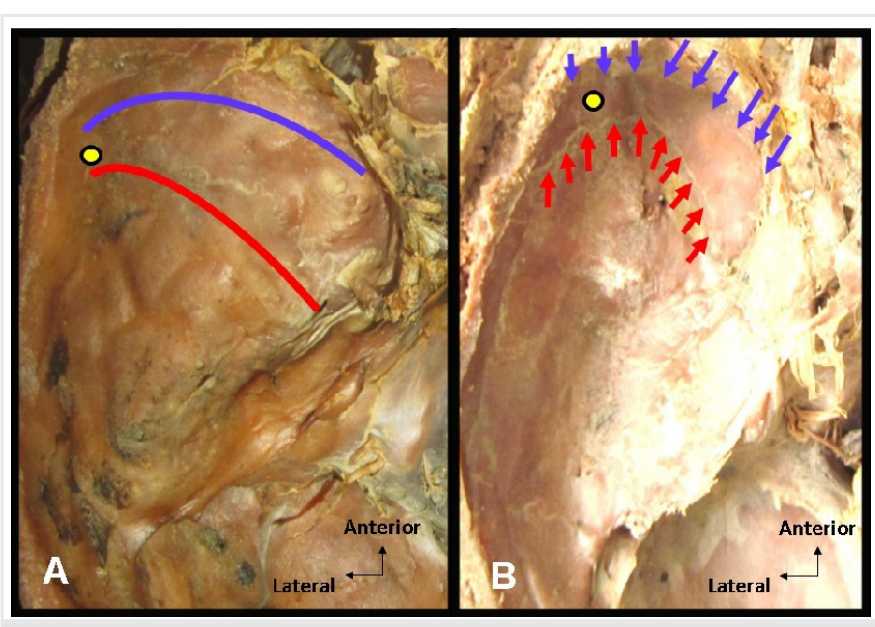

Figure 4. Course of the sinus sphenoparietalis and a. meningea media according to pterion

A) Overlapping of sinus sphenoparietalis and a. meningea media on the pterion. Blue line indicates the course of the sinus sphenoparietalis. Red line indicates the groove of the a. meningea media. Yellow circle indicates the inner surface of the pterion, B) Inner surface of the pterion and its overlapping with the dural sinus and meningeal vessels. Blue arrows: sinus sphenoparietalis, red arrows: Meningeal vessels. Yellow circle indicates the inner surface of the pterion

In order to locate the pterion, different landmarks have been described in the literature, such as arcus zygomaticus or frontozygomatic suture $(2,7)$. In the present study, palpable landmarks under the surface of the skin without any further skin incision were chosen to locate the pterion, such as tuberculum marginale and processus mastoideus. Despite the majority of the previous studies had described the location of the pterion according the closest distance to the landmarks, we used vertical and horizontal distances of pterion to palpable landmarks in order to locate the position more effectively. We think that, according to closest distances, two dimensional description is more effective, especially during surgeries but we do not suggest any superiority of this method.

Thickness of the pterion was reported to be $3-4 \mathrm{~mm}$ which was consistent with our results $(8,9)$. Despite it was reported to be thicker on the left side in Korean population, no significant difference was found in terms of right and left sides in the present study (9).

Internal aspect of the pterion is closely related with Sylvian fissure which is called as sulcus lateralis in Nomina Anatomica. Opercular cortex, Broca's motor speech area, some of the anterior subarachnoid cisterns such as Sylvian cistern are in close neighborhood with inner surface of the pterion (1). In addition, distance of pterion to trigeminal ganglion and its branches, insular cortex, branches of anterior and posterior circulation in the anterior and middle cranial fossa are short.

The pterional approach is one of the most commonly used surgical procedures in neurosurgery. Due to close distance to important anatomical structures, pterional craniotomy was described as an advantageous and functional approach (10). Main objective of the present study was to reveal the relationship of important anatomical structures with inner surface of the pterion. According to our findings, a. meningea media and the sinus sphenoparietalis were the main anatomical structures to be affected in pterional approaches.

In classical anatomy textbooks, a. meningea media was reported to be overlying the inner surface of the pterion $(1,11,12)$. Rather than the main stem of the a. meningea media, anterior or frontal ramus of the artery courses on the internal aspect of the pterion. There is limited metric data about pterion and a. meningea media in the literature. The closest distance between pterion and the stem of the a. meningea media was reported to be $1 \mathrm{~cm}$ by Kalthur et al. (13). Ma et al. (8) reported that the branches of the a. meningea media travels within a $1 \mathrm{~cm}$ diameter circle around pterion. In the present study, foramen spinosum was found to be approximately $4 \mathrm{~cm}$ posteroinferior to pterion. The closest distance of pterion to bifurcation of the artery was found to be $1.7 \mathrm{~cm}$, which was longer than the South Indian population (13). Ma et al. (8) reported that internal aspect of the pterion coincided with the branches of the a. meningea media in $68 \%$ of the samples. In the current study, in $61.4 \%$ of the samples, overlapping of the vessel with pterion was found which was lower than but similar with the previous results.

Trigeminal ganglion is located on the impressio trigeminalis which is at the petrous apex of temporal bone. Layers of the dura mater cover this area and a space is formed between the layers of the dura mater in this region. This space is called the Meckel cave which contains trigeminal ganglion and its branches. This dural space is also in the neighborhood of the parasellar region (14). Thus, Meckel cave is an important surgical intervention area for trigeminal ganglion and cavernous sinus. Distance of Meckel cave to the inner surface of the posterior root of the arcus zygomaticus and lateral tip of the petrous ridge was reported as $26.5 \mathrm{~mm}$ and $38.4 \mathrm{~mm}$, respectively in a previous study (14). In the current study, closest distance of internal aspect of the pterion to Meckel cave was found as $40.6 \mathrm{~mm}$ which was consistent with the literature.

To our knowledge, no previous study has reported the relationship of sinus sphenoparietalis with pterion. The sinus sphenoparietalis courses along the lesser wing of the sphenoid bone. During its course from posterior to medial part of sinus cavernosus; middle meningeal veins, superficial middle cerebral vein, anterior temporal diploic veins, and ophthalmic veins may be drained into sinus sphenoparietalis and larger sinuses are seen in these cases (1). A larger sinus sphenoparietalis may cause complications during pterional approaches. In the present study, overlapping of the dural sinus with inner surface of pterion was found in $81.4 \%$ of the samples.

Main limitation of our study was relatively low sample size. We believe that further studies with larger samples will provide more detailed results. 


\section{Conclusion}

In conclusion, sinus sphenoparietalis and the frontal branch of the a. meningea media are the main anatomical structures overlapping with the internal aspect of the pterion. Since the metric data about the internal aspect of pterion and neighboring anatomical structures are limited in literature, we hope that percentage of the overlapping dural sinus (81.4\%) and meningeal vessel $(61,4 \%)$ that we showed would contribute to the literature. In order to minimize complications, these anatomical structures should be kept in mind during pterional approaches.

\section{Ethics}

Ethics Committee Approval: Ethics committee approval was taken from the local ethical committee (KEAH - 2017 - 1564).

Informed Consent: It was not taken because it was a cadaver work.

Peer-review: Externally peer-reviewed.

\section{Author Contributions}

Concept: S.D., R. M., Design: S.D., R. M., Data Collection and Processing: S.D., R.M., Analysis and Interpretation: S.D., R. M., Literature Search: S.D., R.M., Writing: S.D., R.M.,

Conflict of Interest: The authors have no conflicts of interest to declare.

Financial Disclosure: The authors declared that this study has received no financial support

\section{References}

1. Standring S. Gray's anatomy : the anatomical basis of clinical practice. Forty-first edition. ed. New York: Elsevier Limited; 2016.

2. Adejuwon SA, Olopade FE, Bolaji M. Study of the location and morphology of the pterion in adult nigerian skulls. ISRN Anat 2013;2013:403937.

3. Safaee MM, Englot DJ, Han SJ, Lawton MT, Berger MS. The transsylvian approach for resection of insular gliomas: technical nuances of splitting the Sylvian fissure. J Neurooncol 2016;130:283-

87.

4. Sarkar M, Pillai A. Trans-sylvian Approach to Microvascular Decompression for Trigeminal Neuralgia in Syndromic Cranial Base Settling. Oper Neurosurg (Hagerstown) 2018;15:E9-E12.

5. Fujimoto M, Otsuka N, Ezure H, Moriyama H, Inoue Y, Mori R. Intracranial Bony Canal of the A. meningea media - Morphological and Histological Analysis. Okajimas Folia Anat Jpn 2017;93:119-25.

6. Murphy T. The pterion in the Australian aborigine. Am J Phys Anthropol 1956;14:225-44.

7. Nayak G, Mohanty BB, Das SR. Morphometric study of pterion and its clinical significance. Asian J Pharm Clin Res 2017;10:142-4.

8. Ma S, Baillie LJ, Stringer MD. Reappraising the surface anatomy of the pterion and its relationship to the a. meningea media. Clin Anat 2012;25:330-9.

9. Hwang K, Kim JH, Baik SH. The thickness of the skull in Korean adults. J Craniofac Surg 1999;10:395-9.

10. Yasargil MG, Kasdaglis K, Jain KK, Weber HP. Anatomical observations of the subarachnoid cisterns of the brain during surgery. J Neurosurg 1976;44:298-302.

11. Agur AMR, Dalley AF, Grant JCB. Grant's atlas of anatomy. 13th ed. Philadelphia: Wolters Kluwer Health/Lippincott Williams \& Wilkins; 2013.

12. Sinnatamby CS, Last RJ. Last's anatomy : regional and applied. 12th ed. Edinburgh; New York: Churchill Livingstone/Elsevier; 2011.

13. Kalthur SG, Vangara SV, Kiruba L, Dsouza AS, Gupta C. Metrical and non-metrical study of the pterion in South Indian adult dry skulls with notes on its clinical importance. Marmara Medical Journal 2017;30:30-9.

14. Arslan M, Deda H, Avci E, Elhan A, Tekdemir I, Tubbs RS, et al. Anatomy of Meckel's cave and the trigeminal ganglion: anatomical landmarks for a safer approach to them. Turk Neurosurg 2012;22:317-23. 